\title{
Cognitive Heterogeneity and Economic Voting: A Comparative Analysis of Four Democratic Electorates
}

\author{
Brad T. Gomez University of South Carolina \\ J. Matthew Wilson Southern Methodist University
}

\begin{abstract}
This article examines the cognitive foundations of economic voting in four diverse democratic electorates: Canada, Hungary, Mexico, and Taiwan. We present a theory of heterogeneous attribution, where an individual's level of political sophistication conditions his or her ability to attribute responsibility for economic conditions to governmental actors. In contrast to previous literature, we argue that higher, not lower, levels of political sophistication prompt citizens to "vote their pocketbook." Using data from surveys done in conjunction with recent elections in all of these countries, we find that more politically sophisticated respondents are more likely to make use of pocketbook evaluations in their decisions to support or oppose the incumbent government. These findings both present a significant challenge to the conventional wisdom on political sophistication and economic voting and shed light on the necessary cognitive preconditions for democratic accountability.
\end{abstract}

T he recent explosion in the number of the world's democracies has reinvigorated scholarship both on the capacity of political institutions (e.g., Linz and Stepan 1996; O'Donnell, Schmitter, and Whitehead 1986) and on the fundamental role of an active and informed citizenry in developing civil society (e.g., Booth and Richard 1998; Putnam 1993, 2002). ${ }^{1}$ The challenge in new democracies—as in old-is not only the construction of stable and legitimate institutions but also the cultivation of political information in the electorate. It is not sufficient for government to be responsive to citizen desires; citizens must also be able to hold government accountable. Manin, Przeworski, and Stokes make the point succinctly, stating that "[t]he main difficulty both in instructing governments what to do and in judging what they have done is that we, citizens, just do not know enough" $(1999,23)$. Yet, while scholars trumpet this crucial linkage between citizen knowledge and democratic accountability (Inglehart 1977), we have limited understanding of how individual citizens actually use information in constructing attributions of governmental responsibility. Do citizens attribute responsibility for governmental actions uniformly, or do they differ systematically in their ability to make such attributions? Does added political information help to focus citizens' attributions on central figures, or does political sophistication cause citizens to recognize the limits of any one actor in a political system, thereby generating more diffuse attributions? Such questions speak not only to our conception of democratic accountability, but also to our expectations for democratic citizenries, both new and old.

Perhaps the most prominent way in which scholars have studied democratic accountability is through the phenomenon of economic voting, a context that

Brad T. Gomez is assistant professor of political science, University of South Carolina, Columbia, SC 29208 (gomezbt@sc.edu). J. Matthew Wilson is associate professor of political science, Southern Methodist University, Box 750117, Dallas, TX 75275-0117 (jmwilson@ mail.smu.edu).

The authors wish to thank Tom Hansford, Christopher Kam, Carole Wilson, and Elizabeth Zechmeister for their helpful comments at various stages of this project. We thank Raymond Duch, the Center for Public Opinion at El Centro de Investigación y Docencia Económicas A.C., Mexico, and the Election Study Center at National Chengchi University, Taiwan, for use of their survey data. They bear no responsibility for our interpretation of the data. We also are indebted to the College of Arts and Sciences at the University of South Carolina, the USC Center for Asian Studies and its director, John Fuh-sheng Hsieh, and the John G. Tower Center for Political Studies at Southern Methodist University for their financial assistance with this project.

${ }^{1}$ Freedom House's (2003) survey Freedom in the World reports a 32\% increase in the number of electoral democracies in a short period of time-121 democracies in 2002 versus 92 democracies in 1992.

American Journal of Political Science, Vol. 50, No. 1, January 2006, Pp. 127-145

(C)2006, Midwest Political Science Association

ISSN 0092-5853 
offers a wonderful opportunity to gauge the intermingling of information, cognition, and attribution. Since the publication of Kramer's (1971) classic piece, the literature on economic voting has exploded not only in the American setting but in comparative perspective as well. ${ }^{2}$ The question, of course, is whether and how citizens hold incumbent governments accountable for fluctuations in the economy, rewarding them for upturns and punishing them for reverses. The standard answer, especially in the American context, has been that citizens consider the economic well-being of the nation as a whole when voting for or against incumbent governments-the "sociotropic hypothesis" (Kinder and Kiewiet 1979, 1981) rather than relying on the "simple rationality" of voting their pocketbook. There are exceptions to this generalization, however, especially when evidence is gathered cross-nationally. Some works demonstrate strong pocketbook influences to the exclusion of sociotropic effects (Nannestad and Paldam 1997), while others find weak evidence for any sort of economic voting (Monroe and Erickson 1986). Few scholars offer institutional explanations for these varied findings, and those who do tend to focus on systemic differences between the countries under study (e.g., Powell and Whitten 1993). Still fewer scholars have suggested that within-country, individual-level differences might produce varied economic voting effects (Duch 2001; Gomez and Wilson 2001). Importantly, the overwhelming tendency among scholars is to treat citizens as monolithic, assuming, at least implicitly, that all individuals attribute responsibility in the same manner. As a result, we have little evidence on whether politically sophisticated citizens are more or less likely to hold governments accountable for economic outcomes. Without such evidence, claims like the one made by Manin, Przeworski, and Stokes remain interesting conjectures.

In this article, we explicitly model the extent to which citizens at varying levels of political sophistication are able to attribute economic responsibility to governmental actors. Our approach is both cognitive and comparative. Specifically, we apply a theory of heterogeneous attribution, arguing that an individual's cognitive ability to attribute causal responsibility for sociopolitical phenomena is conditioned strongly by his or her level of political sophistication (Gomez and Wilson 2001, 2003). Citizens who are less cognitively engaged with politics tend to make simple, proximal attributions, while politically sophisticated citizens often make attributions of responsibility to less obvious, distal factors. This postulate

${ }^{2}$ A recent account by Lewis-Beck and Paldam (2000) documents that, during the 1990s alone, over 200 articles were published on economic voting. leads to a nonobvious prediction regarding sophistication and economic voting: pocketbook voting is most likely to occur among individuals who are politically sophisticated, whereas low sophisticates tend to rely exclusively on sociotropic evaluations. This hypothesis runs directly counter to conventional wisdom, which holds that the less informed rely more on personal circumstances than national conditions when making judgments about government economic performance (e.g., Campbell et al. 1960; Fiorina 1981; Delli Carpini and Keeter 1996). By reappraising the cognitive processes underlying attributions of economic responsibility, we not only reevaluate the capacity of citizens to hold government accountable, but also shed new light on the varied and sometimes conflicting findings in the comparative literature on economic voting.

We test our theory using cross-national data, examining voting behavior in four diverse democratic electorates at varying levels of economic development-Canada, Hungary, Mexico, and Taiwan. Our choice of cases makes a compelling test of our theory of heterogeneous attribution. First, the cases differ significantly in institutional form, from a traditional Western parliamentary system, to countries moving away from one-party dominance, to an emerging democracy with a multiparty system and coalition government. The institutional diversity of these cases (about which we provide greater detail below) may vary the difficulty of the attribution problem for citizens. As Powell and Whitten (1993) argue, systems that divide political control between institutions and/or parties inhibit voters' ability to hold any one political actor responsible for governmental performance. Since our theory speaks directly to these more difficult attribution problems, it is imperative that institutional diversity be reflected in our case selection. A second consideration is the relative age of these democratic electorates. Since our theoretical approach is cognitive rather than cultural or institutional, we expect, ceteris paribus, similar patterns across both new and old electorates. While the mean level of political sophistication may vary across these nations, its function in conditioning attributions of economic responsibility should be more stable. By selecting countries at varying stages of democratization and with diverse political structures, we are able to test whether this phenomenon is truly generalizable across individuals and not simply a function of electoral, cultural, or institutional context.

We proceed in five parts. First, we review the extant literature on individual-level economic voting in comparative perspective. The existing evidence, as we shall see, is mixed. We highlight the disparate evidentiary claims, and note how previous scholars have almost uniformly explained the heterogeneity in these findings as a product of 
institutional and cultural differences. We then articulate in full our theory of heterogeneous attribution and derive specific hypotheses regarding the cognitive elements required to attribute economic responsibility. We follow this theoretical presentation with a section discussing issues of data and case selection. After testing our theory empirically, we conclude by discussing the implications of our research for work on economic voting and on democratic accountability more broadly.

\section{Economic Accountability in Comparative Perspective}

That citizens hold elected officials accountable for fluctuations in the economy has become a truism of political life. Whether in the aggregate (e.g., Kramer 1971; Hibbs, Rivers, and Vasilatos 1982) or at the individual level (e.g., Fiorina 1981; Kinder and Kiewiet 1979, 1981), political scientists have accumulated a wealth of evidence regarding the link between economic performance and the electoral fortunes of incumbent governments. Questions about the exact mechanism underlying this relationship remain, however. At the aggregate level, scholars routinely debate which economic indicators are most relevant for electoral outcomes (e.g., Arcelus and Meltzer 1975; Alesina, Londregan, and Rosenthal 1993). Other scholars argue over whether voters are retrospective or prospective in their economic assessments (MacKuen, Erikson, and Stimson 1992; Clarke and Stewart 1994). Yet, these continuing debates notwithstanding, as Duch, Palmer, and Anderson assert, "[o]n the basis of the macro-level evidence alone one would have little reason to doubt that the economy matters" (2000, 635).

At the individual level (our area of interest here), scholarly debate still exists as to whether citizens attribute economic responsibility based on broadly national (sociotropic) or parochial (pocketbook) considerations. To be sure, the preponderance of the evidence suggests that sociotropic considerations outweigh pocketbook concerns in the voter's decision calculus (Alford and Legge 1984; Kinder and Kiewiet 1979, 1981; Lewis-Beck 1988). Indeed, in some cases, evidence of pocketbook voting is negligible or even nonexistent. Lewis-Beck's (1988) five-nation study of European economic voting behavior, for example, demonstrates no relationship between personal economic conditions and vote choice (see also Lancaster and Lewis-Beck 1986). There are, however, notable exceptions to the dominance of sociotropic voting (Fiorina 1981; Kramer 1983; Markus 1988), especially when the comparative literature is examined more fully. Evidence from several studies indicates that citizens in certain democracies are more likely to base their vote choice on personal financial considerations than on broadly national concerns. ${ }^{3}$ Great Britain (Sanders 1999) and Denmark (Nannestad and Paldam 1997) provide the most prominent examples of strictly egocentric behavior. Finally, work on Eastern Europe by Powers and Cox (1997) finds a very limited role for any sort of economic evaluations in structuring vote choice, a point echoed by Harper (2000).

What is especially troubling about the mixed evidence on individual-level economic voting is that scholars offer little theoretical explanation for why citizens in some democracies tend to vote sociotropically, while voters in other countries factor in pocketbook concerns to a much greater extent. Compounding this issue is the fact that most major studies of economic voting tend to treat electorates as largely undifferentiated, ignoring potentially significant and systematic heterogeneity among voters. This theoretical limitation denies the possibility that some citizens might vote solely on sociotropic factors, while others might emphasize pocketbook considerations instead or as well. Such a limitation greatly diminishes our understanding of economic voting behavior and, more generally, of how governmental accountability is constructed in the minds of citizens.

A few studies have suggested the possibility of heterogeneous economic voting behavior, however. Within the comparative politics literature, a handful of scholars have offered explanations for cross-national variation. Most notably, Powell and Whitten argue that institutional arrangements that fragment power tend to muddle citizens' ability to attribute responsibility to any one governmental actor. "If the legislative rules, the political control of different institutions, and the lack of cohesion of the government all encourage more influence for the political opposition, voters will be less likely to punish the government for poor performance...” $(1993,393)$. This explanation provides a compelling rationale for variation in the magnitude of economic voting across nations, but it does little to further our understanding of the tradeoff between sociotropic and pocketbook decision rules, either within or between countries. Lewis-Beck (1983) offers one possible explanation for cross-national variation, contending that the use of alternative decision rules may be a function of cultural differences. He speculates that, in cultures with a stronger sense of individualism, voters may be more likely to attribute credit and blame for personal economic conditions to themselves than to

${ }^{3}$ See Lewis-Beck and Paldam (2000) and Nannestad and Paldam (1994) for a review of the comparative economic voting literature. 
global causes. In such cultures, Lewis-Beck expects comparatively low levels of pocketbook voting.

Political culture (or, at minimum, value orientation) is also among the handful of explanations offered by scholars for within-nation economic voting heterogeneity. Feldman, much like Lewis-Beck, contends that American voters' "belief in economic individualism leads people to accept personal responsibility for their economic conditions, which in turn eliminates any connection between personal well-being and political evaluation" (1982, 446). Also examining the United States, Kinder and Mebane (1983) offer a competing value-based hypothesis, contending that collectivism, rather than individualism, drives the predominance of sociotropic factors over pocketbook considerations. The main problem with these arguments is that they may be specific to or influenced too much by the American case, providing little insight into individual-level heterogeneity within non-American electorates.

An alternative and perhaps more generalizable hypothesis for heterogeneity in economic voting centers on the varying levels of political information (or sophistication) held by voters. Several studies at both the individual and aggregate levels (e.g., Conover, Feldman, and Knight 1986; Krause 1997; Weatherford 1983) argue that less informed voters tend to rely more on personal financial considerations than on collective economic conditions in their vote decision. This widely accepted linkage between information and economic attributions presumes that less informed voters simply bring to bear easily accessible information - their personal financial conditionswhen voting. On one level, this heuristic approach is intuitive, since there would appear to be a nontrivial difference in the information costs required for sociotropic versus pocketbook voting. ${ }^{4}$ Yet we believe that this view is limited, in that it portrays economic voting fundamentally as a problem of information acquisition, without considering the other cognitive limitations faced by citizens at low levels of political information. ${ }^{5}$

${ }^{4}$ While, like others, we believe that sociotropic voting imposes at least marginally greater information costs than pocketbook voting, one should not exaggerate the level of knowledge needed. As Kinder and Kiewiet contend, "[i]t is not necessary for sociotropic voters to undertake a sophisticated analysis of the economy. . . Rather, voters must only develop rough evaluations of national economic conditions, and then credit or blame the incumbent party accordingly" $(1981,131)$.

${ }^{5} \mathrm{~A}$ lack of distinction between cognitive processes is noticeable in a recent account by Duch (2001). He argues that information and trust condition the individual's ability to cast an economic vote. For Duch, high levels of information serve to decrease the ambiguity regarding the link between government policy and economic outcomes - a standard information acquisition thesis. He does not explicitly concede that individuals at varying levels of information might use alternative decision rules.
In reality, the paramount cognitive process involved in economic voting is the individual's ability to attribute responsibility. If information acquisition were the only relevant cognitive factor, we certainly would expect less politically sophisticated citizens to be more likely to vote their pocketbook. However, when the sociotropicpocketbook dichotomy is viewed fundamentally as an issue of attribution, the prediction changes markedly. It should be significantly easier to attribute responsibility for the national economy to the President or Prime Minister than to plausibly connect his or her policies to fluctuations in one's own financial circumstances. The former attribution asks the voter to link relatively proximate cognitive objects-the national economy and the national leader. The latter, by contrast, represents a more distal, and thus more difficult, cognitive linkage-the individual's pocketbook with the national leader. Simply put, despite strong previous claims regarding the simplicity of the decision rule, we argue that pocketbook voting should be most evident among the more politically sophisticated segments of an electorate.

\section{Political Sophistication and Heterogeneous Attribution}

The fundamental cognitive mechanism at work in economic voting is the process of causal attribution (Peffley and Williams 1985). Indeed, the attribution process is fundamental to most human decision making and social knowledge (Fiske and Taylor 1984). Psychologists consider causal attributions to be a powerful force in structuring an individual's attitudes toward the self, emotional arousal, and interpersonal evaluations (e.g., Heider 1958; Hewstone 1989; Petty and Cacioppo 1996). In the political realm, scholars have also noted the key role of causal attributions, showing them to be central in structuring political opinions, particularly evaluations of political leaders (Iyengar 1989) and vote choice (Lau and Sears 1981; Feldman 1982). Indeed, it could be argued that causal attributions are at the heart of all political opinion, especially given that the charge of democratic citizenries is to hold governments accountable for social and political outcomes.

Interpersonal and causal attributions require individuals first to be cognizant of a stimulus and then to associate that stimulus with its rightful source. Inherently, the accuracy of the process is sensitive to the individual's base level of information/knowledge and motivation toward the task (Hilton and Slugoski 1986). Information affects the process in multiple and sometimes confounding ways. Psychologists, for instance, have shown that the 
amount of available, relevant information strongly conditions the ability to make reliable attributions (Zanna, Klosson, and Darley 1976). Yet information may create bias as well. Given that information is typically filtered through the perceptual screens of our predispositions, individuals may possess a biased distribution of information in memory and correspondingly biased attributions of causal responsibility may result. Hetherington (1996), for example, shows that exposure to negative media reports about the economy in 1992 significantly affected voters' evaluation of the U.S. economy and their propensity to cast votes against the incumbent president, George H.W. Bush.

The individual's motivation toward the cognitive task (i.e., his or her interest in the attribution problem) is also vital in the attribution process. Individuals who dislike politics, for example, even though they may be intelligent and/or educated, are likely to make hasty and perhaps inaccurate attributions. Absent the willingness to devote much time and effort to deciphering a causal puzzle, unmotivated individuals are likely to employ simple causal explanations for phenomena, centering on obvious connections. The cognitively engaged individual, on the other hand, may deduce more complex and diffuse attributions of responsibility. Clearly, considering the cognitive requirements of the attribution process and citizens' varying levels of knowledge about and interest in politics, we can no longer assume that all voters will ascribe credit or blame to governmental actors in the same way.

We believe that heterogeneity in attributions of political responsibility is best explained by accounting for an individual's level of political sophistication. Political sophistication is a dual concept, incorporating an individual's level of political awareness and cognitive integration (Luskin 1987), thus tapping the informational and motivational properties of attributions in the political domain. Consistent with Luskin (1987) and Sniderman (1993), we argue that individuals at varying levels of political sophistication will differ in their ability to make associative linkages between problems and their sources. Instead of assuming that individuals uniformly seek to maximize consistency between the elements of their belief system, the sophistication model posits that individuals selectively seek congruence depending upon their level of sophistication (Sniderman, Brody, and Tetlock 1991). Unlike the familiar model of the political belief system advanced by Converse (1964), the sophistication model argues that it is the least sophisticated individuals, not the most, who attempt to maximize proximal consistency among belief elements, bringing closely related political information into congruence. Alternatively, high sophisticates seek distal consistency within their belief systems, linking informa- tion across levels of abstraction and bringing into congruence outlying elements of political information.

The contrasting decision rules employed by individuals at various levels of political sophistication have clear implications for economic voting in mass publics. When low sophisticates receive information about economic conditions, either social or personal, they possess a limited capacity to integrate this information into their understanding of the political world. Because they lack a significant number of political referents, it is difficult for low sophisticates to make associative linkages between economic conditions and other elements of their political belief system. In general, less sophisticated voters will have a limited understanding of the political-economic linkage, thereby making it difficult for them to attribute fluctuations in economic conditions to distinct political actors. Thus, for low sophisticates, attributions of political responsibility are restricted mostly to proximate or local causes. Consequently, less sophisticated voters will tend to identify the most obvious actor in the relevant sphere as being responsible for a given outcome. In the context of pocketbook voting, this logic leads to an hypothesis that runs counter to the conventional wisdom (e.g., Conover, Feldman, and Knight 1986; Delli Carpini and Keeter 1996; Duch 2001): namely, we expect that for low sophisticates, pocketbook economic assessments will not be significantly related to candidate preference. Instead, low sophisticates will tend to attribute personal economic responsibility to the actor most closely associated with their pocketbook - themselves. For these individuals, the cognitive link between their personal finances and national economic policy is too distal, generally speaking, for a politically relevant attribution to be made. Thus, pocketbook voting is not likely to occur among citizens low in political sophistication.

Despite this theoretical claim, one should not conclude that less politically sophisticated citizens never engage in economic voting. In fact, the same cognitive restrictions that limit pocketbook voting in low sophisticates may actually accentuate their propensity to engage in sociotropic voting. While the associative link between the national government and one's personal economic wellbeing may be a difficult one, the cognitive bridge between the national government and the national economy is short. Consistent with our theory, when low sophisticates encounter information regarding the national economy, they tend to attribute responsibility to the most obvious actor-in this case, the head of government. Previous work in the American context has provided substantial evidence for these respective pocketbook and sociotropic voting claims (Gomez and Wilson 2001, 2003). In the U.S. case, citizens low in sophistication show no signs of 
pocketbook voting in either presidential or congressional elections. Yet low sophisticates do vote sociotropically; in fact, they disproportionately center their credit or blame for the national economy on the President, ignoring other relevant actors, such as the U.S. Congress. Applying this theory cross-nationally, where institutional layering and power-sharing arrangements may allow the head of government to be more opaque, provides a more difficult and comprehensive test of the hypotheses.

For political sophisticates, the cognitive processes associated with causal attribution are quite different. When high sophisticates encounter economic data, they tend to integrate this new information with a large number of existing political referents, proximate and distal. Consequently, political sophisticates are more likely to make global, as well as local, attributions. These voters account for the most obvious connections, but they also look beyond the simple attributions, constructing more complex causal stories. As with less sophisticated voters, we expect evidence of sociotropic voting among high sophisticates. The connection between national economic conditions and the policies of the incumbent government is simply too obvious to overlook. Yet high sophisticates may also understand the limits of governmental control of the economy (e.g., interdependence in a global marketplace) or the importance of other governmental actors (e.g., the role of independent central banks). As a result, these individuals may attribute responsibility for the national economy more diffusely, to both governmental and nongovernmental actors. If this is the case, we believe that high sophisticates may actually place relatively less weight on national economic evaluations when constructing their vote choice than do low sophisticates. ${ }^{6}$

The capacity of politically sophisticated individuals to make complex and distal attributions allows for the possibility of pocketbook voting. For these individuals, the complex causal chain that may link national economic policy to one's personal financial situation is possible to trace. While clearly realizing that they bear substantial responsibility for their own economic welfare, high sophisticates are more likely than their less sophisticated counterparts to understand the political-economic linkage (e.g., political-business cycles, partisan differences in tax and spending priorities, etc.) and how changes in a government's economic policies might affect their per-

\footnotetext{
${ }^{6}$ Related work provides evidence that low and high sophisticates differ in their ability to attribute responsibility for national economic conditions in the American case (Gomez and Wilson 2003). In 1998, low sophisticates narrowly focused credit for general economic conditions and the national budget surplus on the President, whereas high sophisticates partitioned responsibility among the President, Congress, business, and others.
}

sonal financial situation. ${ }^{7}$ Thus, it is our belief that if evidence of pocketbook voting exists, it is likely to be found chiefly among the more politically sophisticated. ${ }^{8}$

\section{Data and Cases}

In testing comparatively the implications of our theory of heterogeneous attribution and economic voting, we face a key challenge: to find high-quality surveys containing both personal and national economic assessments as well as viable political knowledge items across a range of diverse and interesting cases. While the survey content requirements are of course primary (without the economic and knowledge items, a test of our theory is impossible), we have not been forced by them to make sacrifices in terms of case selection. Recent elections in Canada, Mexico, Hungary, and Taiwan all provide an opportunity to examine our central hypotheses, while presenting significant variation in cultural, historical, and institutional context. Patterns observed consistently across these diverse settings may reasonably be taken as general phenomena of democratic electorates. Before we turn to an examination of the data, a brief review of the electoral circumstances in these countries is in order.

\section{Canada}

Canada is a well-established parliamentary democracy in the Westminster model. A two-party (or two-party "plus"-see Epstein 1964) system had prevailed since confederation in the nineteenth century, with a norm of Liberal governments punctuated by occasional Tory electoral

\footnotetext{
${ }^{7}$ In his classic critique of the sociotropic versus pocketbook debate, Kramer admonished scholars to be aware that "individual welfare actually consists of two unobservable components, a governmentinduced (and politically relevant) component, and an exogenous component caused by life-cycle and other politically irrelevant factors" $(1983,92)$. Our theory is consistent with Kramer's point. Just as political scientists must recognize the duality of individual welfare, so too must voters. Simply put, our theory suggests that sophisticated voters are more likely to recognize the government-induced component of their personal economic welfare than low sophisticates. Consequently, high sophisticates should be more likely than low sophisticates to vote their pocketbook.

${ }^{8}$ For pocketbook voting to occur, sophisticated voters need not ascribe exclusive (or even primary) responsibility for their personal financial situation to the incumbent government. Indeed, the same propensity to divide credit or blame among multiple governmental actors in the sociotropic voting context should operate similarly when it comes to pocketbook voting. Yet as long as some appreciable measure of credit or blame for pocketbook circumstances is attributed to the incumbent government, pocketbook voting is likely.
} 
successes. The federal election of 2000, however, occurred during a period of flux in the national party system. A sweeping Liberal victory in 1993, coupled with the rise of the nascent Reform Party, had dealt a devastating blow to Canada's traditional second party, the Progressive Conservatives. Thus, both the 1997 and 2000 elections saw four major parties, including the humbled Conservatives, vying for official opposition status, while the Liberals, though virtually assured a plurality, struggled for a national majority in the face of four viable partisan alternatives. The 2000 election was a single-member district, plurality-rule contest in which the incumbent Liberals under Jean Chretien sought to defend and expand their majority in relatively healthy economic times. They were opposed by the aforementioned Progressive Conservatives, the more rightist Canadian Alliance (successor to the Reform Party), the nationalist Bloc Quebecois, and the leftist New Democratic Party. Ultimately, the incumbent Liberals were successful, winning 172 of 301 seats (though with only $41 \%$ of the total national popular vote). ${ }^{9}$

For our analysis of the Canadian case, we use data from the 2000 Canadian Election Study. The survey, conducted jointly by researchers at the University of Montreal, McGill University, and the University of Toronto, provides approximately 2,800 complete telephone interviews of a representative sample of Canadians. In addition to basic demographic and political preference items, the Canadian study contains a variety of both political knowledge and attribution items, including a direct query as to whether respondents credit or blame the national government for their own personal economic circumstances. These data are almost ideally suited for testing the hypotheses that we outline above. ${ }^{10}$

\section{Mexico}

Our remaining cases present elections in countries dealing with various stages and types of democratization. First among these is Mexico, which in the late 1980s began a slow transition away from one-party dominance and electoral corruption toward a genuinely competitive, three-party system at the national level. Mexico is a presidential system with a separately elected Congress chosen through a combination of single-member districts and proportional representation. Prior to 1997, the dominant

${ }^{9}$ For a more detailed discussion of the 2000 Canadian election, see LeDuc (2002).

${ }^{10}$ As with all of our cases, details on the political knowledge items and sophistication scale construction can be found in the appendix. For more information on the 2000 Canadian Election Study, see http://www.fas.umontreal.ca/pol/ces-eec/index.html.
Partido Revolucionario Institucional (PRI) had won every presidential and legislative election since 1929, often by suspiciously large margins. The 1997 legislative elections, however, represented a watershed in Mexican political history. For the first time, elections were run under the auspices of the independent Federal Electoral Institute, and thus were largely beyond the control of local PRI bosses. Moreover, two opposition parties had reached true national viability- the conservative National Action Party (PAN) and the leftist Democratic Revolutionary Party (PRD). While these two opposition parties had significant ideological differences, they were united in their desire for true democratization in Mexico and in their criticism of PRI economic policies. President Zedillo's decision in late 1994 to devalue the Peso, while welcomed internationally and perhaps necessary in the long term, had touched off an economic crisis in Mexico, spiking inflation and stifling economic growth. Thus, the incumbent PRI, while virtually assured of remaining the largest single party in the Congress, risked losing majority status in the Chamber of Deputies to a unified opposition. In the end, this in fact happened, as the PRI won 239 of 500 seats based on a mere $40 \%$ of the total national popular vote. This stunning defeat for the traditionally hegemonic party paved the way for PAN candidate Vicente Fox's historic capture of the presidency in $2000 .{ }^{11}$

In examining economic voting in the 1997 Mexican legislative elections, we rely on a study conducted by the survey research unit of the Centro de Investigacion $y$ Docencia Económicas, or CIDE. This national faceto-face survey of approximately 2,000 Mexican households contains, in addition to vote choice questions, both a battery of political knowledge items (as detailed in the appendix) and pocketbook and sociotropic economic evaluations. Complete questionnaires and data from this survey are available from CIDE's library division (http://www.cide.edu/biblioteca.htm).

\section{Hungary}

The Hungarian national election of 1998 provides another case of party competition in the wake of recent democratization. Like most of the former communist nations of Eastern Europe, Hungary faced a period of political uncertainty and economic dislocation following the collapse of its Soviet-backed authoritarian regime. Quickly establishing a proportional representation, parliamentary system, Hungary became one of the first nations in Eastern Europe to hold truly free and democratic

\footnotetext{
${ }^{11}$ For more on the 1997 Mexican legislative election, see Klesner
} (1997). 
elections. Anticommunist, reformist forces swept to victory in the country's first such election in 1990, only to be defeated by the reconstituted communists in 1994 after several years of the economic hardship that inevitably accompanies transition to free markets. The 1998 campaign was waged against a backdrop of continued widespread discontent about Hungary's economy, but with some signs that things were beginning to improve. In this election, the governing coalition of the Hungarian Socialist Party (MSZP - the former communists) and the Alliance of Free Democrats (SZDSZ) faced opposition from a variety of parties, principally from the center-right Federation of Young Democrats (FIDESZ) and Hungarian Civic Party (HCP). The election was in many respects a referendum on the governing coalition's compliance with the bulk of IMF demands for restructuring the economy, creating an ironic situation in which the former communists were defending their decision to undertake painful economic reforms while the "reformist" parties criticized them for it. Ultimately, the opposition did prevail-the MSZP-SZDSZ coalition lost its parliamentary majority. ${ }^{12}$

Our study of economic voting in the 1998 Hungarian election makes use of a survey administered jointly by the University of Houston (under the supervision of Raymond Duch) and an Hungarian firm, Ezredvég Alapitvany, in the 1997 pre-election period. The survey sampled approximately 1,500 Hungarian households and included questions on economic assessments and political knowledge (though these were not as extensive as in our other surveys-see the appendix). The data from this survey are publicly available through the University of Houston's Democracy and Markets Project (http://www.uh.edu/democracy/dmarkets.htm).

\section{Taiwan}

Finally, the 2001 Taiwanese Legislative Yuan elections present some elements that are similar to our other cases and some that are distinctive. Like Mexico, Taiwan had long borne the oxymoronic label of "one-party democracy." The Kuomintang (KMT) had been the dominant party on the island since the flight from mainland China in the late 1940s, but had suffered an historic and humiliating defeat when Chen Shui-bian of the Democratic Progressive Party (DPP) captured the presidency in 2000. Also like Mexico, the Taiwanese political system is a presidential (some would say "semi-presidential"— - see Hsieh 2003) one with a separately elected legislature chosen through

\footnotetext{
${ }^{12}$ Duch (2001) provides a more detailed discussion of the 1998 Hungarian election.
}

a combination of geographic constituencies and proportional representation. Taiwan differs from Mexico (and indeed all of our other cases), however, in two key respects. First, the 2001 legislative elections were run under conditions of divided government-the DPP controlled the presidency, but the KMT remained the dominant faction in the Legislative Yuan. Thus, President Chen was seeking not to maintain a legislative majority, but to capture one, and the election was seen largely as a referendum on his economic performance and greater openness to the idea of Taiwanese independence. Second, although many parties hold at least token representation in the Legislative Yuan, Taiwan has a de facto two-party system, with the major factions aligning themselves into "blue" and "green" coalitions. The Blue Coalition is comprised of the KMT and their allies, the New Party and the People First Party, all of whom were opposed to President Chen. The Green Coalition formed in support of the president and was comprised of his own party, the DPP, and the Taiwan Solidarity Union. Despite the generally unfavorable national economic conditions prevailing at the time, the Green Coalition was moderately successful in its electoral objectives-while they did not capture a legislative majority, they did for the first time in history deny the KMT majority status. Allies of President Chen emerged from the election with a plurality in the Legislative Yuan. ${ }^{13}$

A 2001 Taiwanese Election Study conducted by researchers in the Election Study Center at National Chengchi University (http://www2.nccu.edu. tw/ s00/eng/index.htm) allows us to examine political sophistication and economic voting in the Taiwanese case. This study was based on a probability sample of approximately 1,200 Taiwanese residents and was conducted in the period leading up to the balloting. As in the previous cases, the survey contains three key elements for our analysis: partisan vote choice, economic assessments, and political knowledge items (though, regrettably, these are relatively easy questions, resulting in less variance and greater skew than we would ideally like).

Clearly, the cases that we analyze here, while driven in part by data requirements, present great variation along a host of salient dimensions. We have here presidential systems and parliamentary ones, wealthy nations and developing ones, new democracies and old. We are also allowed (forced?) by the surveys to operationalize political sophistication using varied sets of knowledge items. Inevitably, there will be questions about the appropriateness of a particular knowledge item in a particular

\footnotetext{
${ }^{13}$ For additional discussion of the 2001 Taiwanese election, see Schafferer (2003).
} 
case, or about the direct comparability of sophistication scales. Our goal, however, is to examine the robustness of our theory in the face of all of these variations. We seek to show, using models as consistent as possible across countries given political variations and data constraints, that pocketbook voting as a general phenomenon is more prevalent among high than among low sophisticates, defying the conventional wisdom in the field. We now turn to an explanation and presentation of these models.

\section{Models and Results}

The key to establishing that political sophistication conditions economic voting is to show that pocketbook evaluations are systematically related to support for the incumbent government among the more sophisticated but not among the less sophisticated. Our expectation of such a result rests on the assumption, as outlined above, that politically sophisticated respondents are more likely to make a cognitive link between government policy and their own economic well-being. Before presenting our core models of interest, it is instructive to examine this underlying premise directly. Data from the 2000 Canadian Election Study present an opportunity for such a test. Respondents to that survey who reported some change in their household economic fortunes were asked if they believed that the policies of the federal government were responsible for that change (similar questions are, regrettably, not present in our other cases). Based on these responses, we construct a dichotomous dependent variable, coded 1 for respondents who do attribute credit or blame to government and 0 for those who do not. According to our theory, political sophistication should be a significant and positive predictor of one's likelihood of attributing responsibility for personal economic conditions to government.

Of course, there are several competing hypotheses for which we must control. One such possible explanation is that more sophisticated respondents may differ appreciably from less sophisticated ones in their average assessments of pocketbook economic conditions (offered on a three-point scale ranging from "worse off" to "better off" as compared to the previous year). As has been demonstrated previously (Bandura 1982; Madsen 1987), people are much more likely to make self-attributions for positive outcomes than for negative ones. Thus, systematic differences in pocketbook assessments by level of sophistication could influence patterns of attribution in the electorate, quite apart from any cognitive disparities. Another potential confounding factor here is party identification. Identifiers with the left-leaning Liberal party in Canada may be more inclined to see government as a major influence on personal economic conditions than more conservative respondents. More important, however, are interactions. Ceteris paribus, Liberal party identifiers should be more likely to credit Liberal governments if they have personal economic success, and less likely to blame Liberal governments for their own economic downturns, than loyalists of other parties (using those without party identification as the omitted control group). Finally, these partisan rationalizations may be most prominent among the parties' more sophisticated adherents, giving rise to a final set of interactions. We test all of these explanations, including our sophistication hypothesis, simultaneously in a multivariate model.

Table 1 reports maximum-likelihood probit estimates and changes in predicted probabilities $(\Delta)$ for each variable. Clearly, all of the expected relationships hold. Liberal identifiers are more likely to credit the government for good fortunes and less likely to blame it for bad ones than are independents or (especially) other partisans. Additionally, respondents are more likely to see the government as responsible for negative economic developments in their personal lives than for positive ones. Most importantly, however, even controlling for these factors, political sophistication remains a significant predictor of whether an individual will make the distal link between national economic policy and personal financial circumstances. The most sophisticated respondents are 25 percentage points more likely, all else equal, to credit or blame the national government for changes in their own economic well-being than are the least sophisticated ones. These results provide support for the theoretical underpinnings of our argument, suggesting that the link between political sophistication and attributional processes is genuine.

While such theoretical validation is reassuring, the bottom line remains whether political sophistication shapes the nature of economic voting across a variety of electoral contexts. For an answer, we turn to our models of partisan vote choice in four democratic electorates. For purposes of comparison, we have sought to make these models as consistent across countries as possible, subject of course to necessary variations arising from the modeling of idiosyncratic electoral influences and from the availability of items in our four surveys. Each model includes key ethnic and/or geographic variables in the respective countries, as well as demographic controls for gender, age, education, and income. In each model, we include individuals' self-placements on the 


\section{TABle 1 Probit Model: Credit/Blame of National Government for Personal Economic Circumstances (Canada, 2000)}

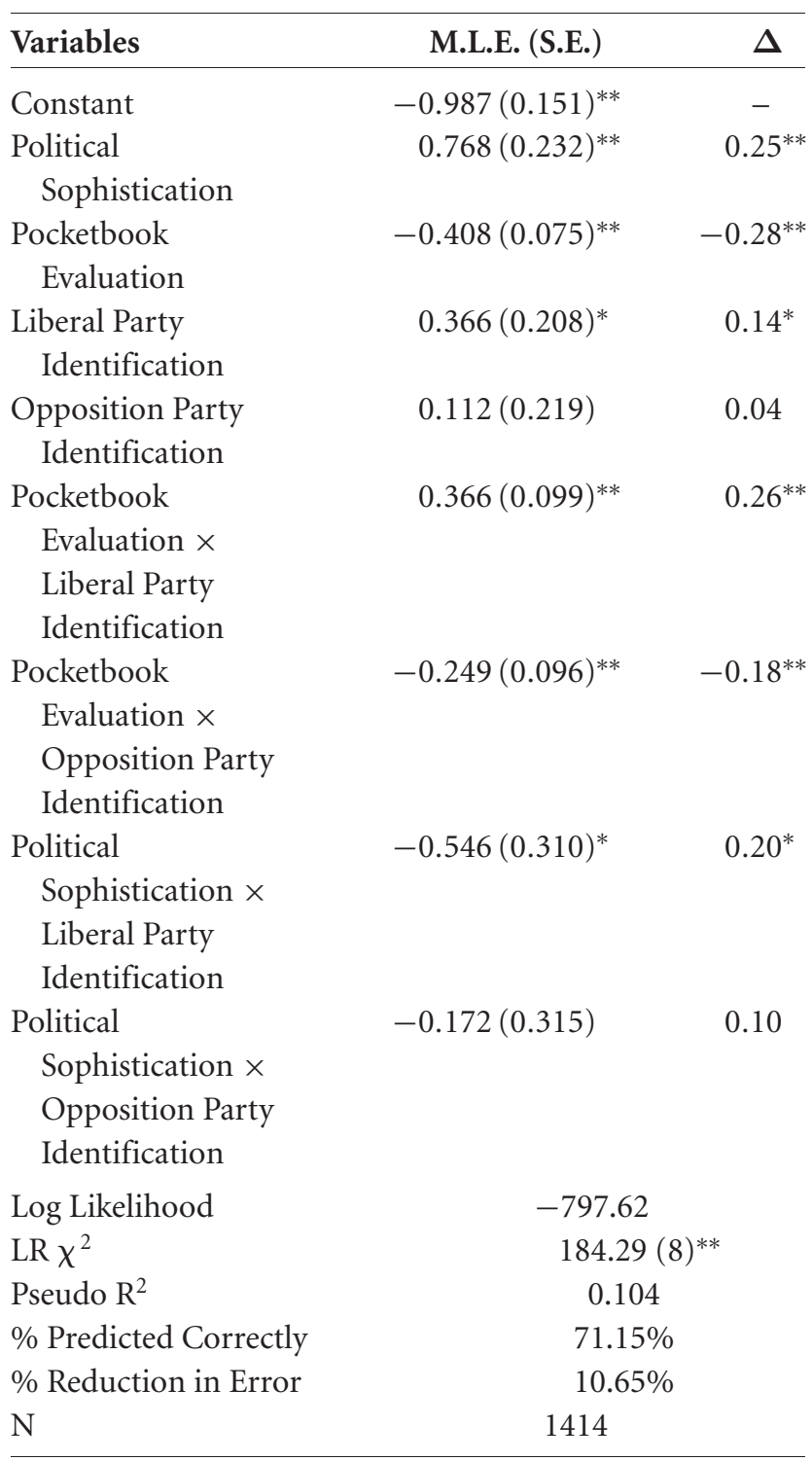

Note: Marginal effects $(\Delta)$ indicate the change in the predicted probability of $Y$ given a discrete change in $X$ from its minimum to maximum, while holding other variables at their mean values (logical values for mutually exclusive variables). Marginal effects computed using Clarify (King, Tomz, and Wittenberg 2000). ${ }^{* *} \mathrm{p}<.01$, one-tailed test; ${ }^{*} \mathrm{p}<.05$, one-tailed test.

left-right political spectrum. ${ }^{14}$ In addition, where available, we have included terms capturing identification with the governing party. ${ }^{15}$ To this we have added respondents' positions on such issue items as are available in the various

\footnotetext{
${ }^{14}$ For both the ideology and issue items, higher values indicate more "leftward" positions.

${ }^{15}$ These terms are straightforward in Canada and Mexico, as voters are asked which party they feel closest to. We have coded responses
}

surveys-four in each case. ${ }^{16}$ Finally, to test our theory, we include interactions between respondents' assessments of both personal and national economic circumstances and political sophistication, as well as the constituent parts of these interactions. In every model, the dependent variable is dichotomous, with votes for the incumbent party (or coalition) coded 1 and votes for any other party coded $0 .{ }^{17}$

\section{Vote-Choice Models}

Tables 2 through 5 present our vote-choice models for each country. In each case, our key concept of interest is the interaction between political sophistication and pocketbook evaluations. However, recalling that multiplicative

of "Liberal" and "PRI" (respectively) as 1 and all other responses as 0 . In the Hungarian study, there is no party identification measure per se; however, as an admittedly imperfect proxy, we have incorporated a measure of whether the respondent was a member of the Communist Party prior to democratization (since the reconstituted Communists were the leading partner in the governing coalition going into the 1998 elections). We omit party identification in the Taiwanese model, as no suitable item is available in the survey.

${ }^{16}$ In the case of Canada, these issue items measure support for more stringent gun control, recognition of same-sex marriages, more liberal immigration laws, and increased taxes to fund expanded social services. In Mexico, the issues include support for government ownership of vital industries and utilities, renewed negotiations with the Zapatista guerrillas, the North American Free Trade Agreement, and increased efforts to punish corruption. In Hungary, the issue items tap support for general government control of the economy, continued government pension guarantees, intervention in the affairs of neighboring countries to protect Hungarians abroad, and a separationist position on Church-state relations. Finally, in the Taiwanese case, the available issue items measure support for unification with mainland China, greater environmental spending, a stronger welfare state, and government reform. It should be noted that in no case does the omission of these issue items significantly alter the core results of interest.

${ }^{17}$ We opt for dichotomous coding, despite the fact that all four of our cases are multiparty systems, for several reasons. Practically, it makes for a much clearer and easier presentation of our findings. Four countries in multiple pairwise comparisons of partisan alternatives would quickly become unwieldy. In addition, at least two of these countries, despite their multiple parties, present voters with functionally dichotomous choices. In Taiwan, all of the major parties group themselves for electoral purposes into the "Blue" and "Green" coalitions (Schafferer 2003). In Mexico, Dominguez and McCann (1996) argue that the fundamental vote choice process is dichotomous, as people select either PRI or generic "opposition." Finally, in at least two of these countries (Canada and Mexico), only the dominant, incumbent party is truly a national one. Thus, while three, four, or more parties may be competitive nationally, an individual voter will often face a choice between the incumbents and a single viable opposition candidate. All of these reasons, combined with the fundamentally dichotomous, up or down, referendum nature of economic voting (Downs 1957; Fiorina 1981), lead us to use simple probit as opposed to a multinomial model specification. 


\section{TABle 2 Probit Model: Political Sophistication and Economic Voting in Canada (2000)}

\begin{tabular}{|c|c|c|}
\hline Variables & M.L.E. (S.E.) & $\Delta$ \\
\hline Constant & $0.137(0.197)$ & - \\
\hline Black & $0.637(0.484)$ & 0.23 \\
\hline Asian & $0.580(0.263)^{*}$ & $0.22^{*}$ \\
\hline Native & $-0.025(0.382)$ & -0.01 \\
\hline Francophone & $-0.033(0.161)$ & -0.01 \\
\hline Female & $0.071(0.076)$ & 0.03 \\
\hline Age & $-0.007(0.002)^{* *}$ & $-0.18^{* *}$ \\
\hline Income & $-0.020(0.013)$ & -0.07 \\
\hline Education & $-0.033(0.020)^{*}$ & -0.12 \\
\hline Western Canada & $-0.062(0.097)$ & -0.02 \\
\hline Eastern Canada & $-0.131(0.121)$ & -0.05 \\
\hline Quebec & $-0.560(0.172)^{* *}$ & $-0.20^{* *}$ \\
\hline Liberal Party ID & $0.733(0.029)^{* *}$ & $0.84^{* *}$ \\
\hline Ideology & $0.113(0.063)^{*}$ & $0.08^{*}$ \\
\hline Gun Control & $0.026(0.030)$ & 0.03 \\
\hline Gay Marriage & $0.035(0.033)$ & 0.04 \\
\hline Taxes & $0.186(0.074)^{* *}$ & $0.07^{* *}$ \\
\hline Immigration & $0.007(0.057)$ & 0.00 \\
\hline $\begin{array}{l}\text { Political } \\
\text { Sophistication }\end{array}$ & $-0.330(0.152)^{*}$ & $-0.12^{*}$ \\
\hline $\begin{array}{l}\text { Sociotropic } \\
\text { Evaluation }\end{array}$ & $0.120(0.144)$ & 0.09 \\
\hline $\begin{array}{l}\text { Pocketbook } \\
\text { Evaluation }\end{array}$ & $-0.107(0.128)$ & -0.08 \\
\hline $\begin{array}{l}\text { Sophistication } \times \\
\text { Sociotropic } \\
\text { Evaluation }\end{array}$ & $0.016(0.200)$ & 0.01 \\
\hline $\begin{array}{l}\text { Sophistication } \times \\
\text { Pocketbook } \\
\text { Evaluation }\end{array}$ & $0.545(0.184)^{* *}$ & $0.39^{* *}$ \\
\hline Log Likelihood & \multicolumn{2}{|c|}{-797.27} \\
\hline $\operatorname{LR} \chi^{2}$ & \multicolumn{2}{|c|}{$720.83(22)^{* *}$} \\
\hline Pseudo $\mathrm{R}^{2}$ & \multicolumn{2}{|c|}{0.438} \\
\hline$\%$ Predicted Correctly & \multicolumn{2}{|c|}{$85.41 \%$} \\
\hline \% Reduction in Error & \multicolumn{2}{|c|}{$59.31 \%$} \\
\hline $\mathrm{N}$ & \multicolumn{2}{|c|}{2125} \\
\hline
\end{tabular}

Note: Marginal effects $(\Delta)$ indicate the change in the predicted probability of $Y$ given a discrete change in $X$ from its minimum to maximum, while holding other variables at their mean values (logical values for mutually exclusive variables). Marginal effects computed using Clarify (King, Tomz, and Wittenberg 2000).

${ }^{* *} \mathrm{p}<.01$, one-tailed test; ${ }^{*} \mathrm{p}<.05$, one-tailed test.

terms are nonlinear and must be interpreted only in concert with their constitutive terms (Brambor, Clark, and Golder 2006; Friedrich 1982), we calculated the marginal effects (and standard errors) of pocketbook evaluations on vote choice at varying levels of political sophistica- tion for each country. ${ }^{18}$ These results are reported in Table 6, which should be viewed in conjunction with the vote-choice models themselves.

Table 2 presents the results of our vote-choice model for the 2000 Canadian elections. Here, the dependent variable is vote for candidates of the incumbent Liberal party. A few of the demographic items are important: Asian voters are more favorable toward the Liberals than others, while older, more educated, and Quebecois voters are less so. Among the issue items, only the question of taxes has any great effect. Not surprisingly, identification with the Liberal party makes voters dramatically more likely to support its candidates, and ideology also exerts some influence, with voters on the left more likely to support the Liberals. ${ }^{19}$ The effects of sociotropic voting are nonsignificant, a result unaffected by an interaction with sophistication. With pocketbook voting, however, we see sharp differences by sophistication. This is reflected both in the significant coefficient on the interaction term and, more importantly, in the values reported in Table 6. Here we see no evidence of pocketbook voting for those below the sophistication mean, with effects first appearing for those near the mean level of sophistication and increasing as we move up the sophistication scale. As expected, there is no evidence of any pocketbook effects among the less sophisticated, but strong evidence among sophisticated voters. High sophisticates whose personal circumstances had improved were 39 percentage points more likely to vote Liberal than high sophisticates whose personal circumstances had worsened, a substantive effect greater than any other in the model except party identification.

Very similar patterns emerge in Table 3 , which reports results of our model of voting in the 1997 Mexican legislative elections. Here, the dependent variable is vote for PRI congressional candidates. The demographic items in this case are a mixed bag, with Indians, women, and those in the South more likely to support PRI candidates and the

\footnotetext{
${ }^{18}$ Since our measures of sophistication differ somewhat across countries, we calculated the results at each country's mean level of sophistication, as well as \pm 1 and \pm 2 standard deviations from the mean.

${ }^{19}$ Supplementary analyses, available from the authors, reveal that ideology is strongly influential in the vote choice of more sophisticated respondents, but of little or no importance to less sophisticated voters. This finding, replicated to varying degrees in all of the countries examined here, provides some confirmation of the validity of our sophistication measures. As a variety of scholars have demonstrated (Converse 1964; Jacoby 1995; Knight 1985), less sophisticated individuals generally lack the cognitive capacity to understand politically abstract concepts like "left" and "right," and thus tend to make less use of ideology in their political choices. This would explain why, in all of these counties, left-right self-placement influences vote choice more powerfully for high sophisticates than for low.
} 


\section{TABLE 3 Probit Model: Political Sophistication and Economic Voting in Mexico (1997)}

\begin{tabular}{|c|c|c|}
\hline Variables & M.L.E. (S.E.) & $\Delta$ \\
\hline Constant & $-1.521(0.302)^{* *}$ & - \\
\hline Indian & $0.306(0.166)^{*}$ & $0.10^{*}$ \\
\hline Female & $0.328(0.122)^{* *}$ & $0.10^{* *}$ \\
\hline Age & $-0.001(0.079)$ & -0.00 \\
\hline Income & $0.014(0.045)$ & 0.03 \\
\hline Education & $-0.045(0.035)$ & -0.11 \\
\hline Northern States & $0.142(0.166)$ & 0.05 \\
\hline Southern States & $0.290(0.161)^{*}$ & $0.09^{*}$ \\
\hline PRI Party ID & $2.126(0.153)^{* *}$ & $0.70^{* *}$ \\
\hline Ideology & $0.067(0.018)^{* *}$ & $0.19^{* *}$ \\
\hline Govt Ownership & $-0.173(0.083)^{*}$ & $-0.10^{*}$ \\
\hline Guerrillas & $-0.034(0.035)$ & -0.05 \\
\hline NAFTA & $0.026(0.046)$ & 0.02 \\
\hline Corruption & $0.001(0.017)$ & 0.01 \\
\hline $\begin{array}{l}\text { Political } \\
\text { Sophistication }\end{array}$ & $0.096(0.265)$ & 0.03 \\
\hline $\begin{array}{l}\text { Sociotropic } \\
\text { Evaluation }\end{array}$ & $0.167(0.119)$ & 0.21 \\
\hline $\begin{array}{l}\text { Pocketbook } \\
\text { Evaluation }\end{array}$ & $-0.094(0.063)$ & -0.17 \\
\hline $\begin{array}{l}\text { Sophistication } \times \\
\text { Sociotropic } \\
\text { Evaluation }\end{array}$ & $-0.032(0.194)$ & -0.03 \\
\hline $\begin{array}{l}\text { Sophistication } \times \\
\text { Pocketbook } \\
\text { Evaluation }\end{array}$ & $0.192(0.105)^{*}$ & $0.33^{*}$ \\
\hline Log Likelihood & -285.33 & \\
\hline $\operatorname{LR} \chi^{2}$ & $286.24(18)^{* *}$ & \\
\hline Pseudo $\mathrm{R}^{2}$ & 0.420 & \\
\hline$\%$ Predicted Correctly & $87.36 \%$ & \\
\hline \% Reduction in Error & $60.75 \%$ & \\
\hline $\mathrm{N}$ & 823 & \\
\hline
\end{tabular}

Note: Marginal effects $(\Delta)$ indicate the change in the predicted probability of $Y$ given a discrete change in $X$ from its minimum to maximum, while holding other variables at their mean values (logical values for mutually exclusive variables). Marginal effects computed using Clarify (King, Tomz, and Wittenberg 2000).

${ }^{* *} \mathrm{p}<.01$, one-tailed test; ${ }^{*} \mathrm{p}<.05$, one-tailed test.

other items falling short of significance. As expected, identification with the PRI is strongly predictive of support for its candidates, and left-right ideology also matters, with those on the left more likely to vote PRI than those on the right. The issue items in the model are of limited importance, with only the government ownership question playing a discernible role in vote choice. On the key ques- tion of economic evaluations, the results are again consistent with our hypothesis: pocketbook voting is confined to the more sophisticated portion of the Mexican electorate. Politically sophisticated Mexican voters whose household financial circumstances had improved in 1997 were 33 percentage points more likely to support PRI candidates than were those whose circumstances had worsened. Indeed, the analysis in Table 6 reveals pocketbook-voting effects only among the most sophisticated Mexicans, with the effect approaching significance in the opposite direction for the least sophisticated.

The case is less clear with the model of the 1998 Hungarian national elections, presented in Table 4. In this case, the dependent variable is a vote for candidates of the ruling coalition (either the MSZP or the SZDSZ). The demographic variables in this model have little effect-only gender appears to matter for vote choice. Self-reported ideology exerts a strong influence on vote choice, with the most leftist respondents fully 67 percentage points more likely to support the governing coalition than those furthest to the right. Of the issue items, only the question of Hungarians abroad question is significant, and its substantive effects are modest. On our key items of interest, the economic measures, the results are mixed for our hypotheses. The sociotropic term is strongly predictive of vote choice, but neither the pocketbook term nor either of the interactions is. Moreover, looking at Table 6, we find evidence of pocketbook voting only among those at the middle of the sophistication scale- there is no statistically discernible effect for those in either the highest or lowest categories. Thus, while our expectation that there would be no evidence of pocketbook voting among the least sophisticated is again borne out in this case, we do not see the emergence of pocketbook voting at the highest levels of sophistication that we do in Canada and Mexico.

Finally, we turn to our model of vote choice in the 2001 Taiwanese legislative midterm elections (see Table 5). Here, the dependent variable is vote for candidates of the "Green Coalition," the legislative bloc supporting the incumbent President Chen. Note that these results should be viewed as more tentative than those from the other models, for a couple of reasons. First, since this election is a legislative midterm under conditions of divided government, the targets for economic voting are potentially ambiguous, a situation discussed in the American context by Gomez and Wilson (2003). More importantly, the clustering of responses to the relatively easy information items presented in the Taiwanese survey hampers the sophistication scale (see the appendix). With these caveats in mind, however, we can report that the Taiwanese case also provides support for our key hypotheses. A couple of demographic variables matter, with the well educated and those 


\section{TABle 4 Probit Model: Political Sophistication and Economic Voting in Hungary (1998)}

\begin{tabular}{|c|c|c|}
\hline Variables & M.L.E. (S.E.) & $\Delta$ \\
\hline Constant & $0.722(0.389)^{*}$ & - \\
\hline Female & $0.361(0.111)^{* *}$ & $0.14^{*}$ \\
\hline Age & $0.004(0.004)$ & 0.13 \\
\hline Income & $0.032(0.037)$ & 0.07 \\
\hline Education & $-0.022(0.051)$ & -0.06 \\
\hline Former Communist & $0.230(0.160)$ & 0.09 \\
\hline Ideology & $-0.218(0.028)^{* *}$ & $-0.67^{*}$ \\
\hline Govt Control of Econ & $-0.022(0.021)$ & -0.08 \\
\hline Pensions & $0.110(0.072)$ & 0.16 \\
\hline Hungarians Abroad & $-0.034(0.018)^{*}$ & $-0.12^{*}$ \\
\hline $\begin{array}{l}\text { Church/State } \\
\text { Relations }\end{array}$ & $0.003(0.021)$ & 0.01 \\
\hline $\begin{array}{l}\text { Political } \\
\text { Sophistication }\end{array}$ & $0.039(0.271)$ & 0.02 \\
\hline $\begin{array}{l}\text { Sociotropic } \\
\text { Evaluation }\end{array}$ & $0.328(0.161)^{*}$ & $0.48^{*}$ \\
\hline $\begin{array}{l}\text { Pocketbook } \\
\text { Evaluation }\end{array}$ & $0.227(0.192)$ & 0.32 \\
\hline $\begin{array}{l}\text { Sophistication } \times \\
\text { Sociotropic } \\
\text { Evaluation }\end{array}$ & $0.111(0.255)$ & 0.13 \\
\hline $\begin{array}{l}\text { Sophistication } \times \\
\text { Pocketbook } \\
\text { Evaluation }\end{array}$ & $-0.135(0.300)$ & -0.15 \\
\hline Log Likelihood & -374.88 & \\
\hline $\operatorname{LR} \chi^{2}$ & $175.84(15)^{* *}$ & \\
\hline Pseudo $R^{2}$ & 0.203 & \\
\hline$\%$ Predicted Correctly & $70.25 \%$ & \\
\hline$\%$ Reduction in Error & $38.63 \%$ & \\
\hline $\mathrm{N}$ & 679 & \\
\hline
\end{tabular}

Note: Marginal effects $(\Delta)$ indicate the change in the predicted probability of $Y$ given a discrete change in $X$ from its minimum to maximum, while holding other variables at their mean values (modal values for dichotomous variables). Marginal effects computed using Clarify (King, Tomz, and Wittenberg 2000).

${ }^{* *} \mathrm{p}<.01$, one-tailed test; ${ }^{*} \mathrm{p}<.05$, one-tailed test.

of mainland Chinese origin more likely to support candidates of the Blue coalition. Issues and ideology play an important role, with ideological self-placement and positions on unification and the welfare state strongly shaping vote choice. Finally, in terms of the economic items, the results are again somewhat mixed. The sociotropic term is significant, but the pocketbook terms and the interactions all fall short. Turning to Table 6, however, we do see a pattern roughly consistent with what we would predict-
TABle 5 Probit Model: Political Sophistication and Economic Voting in Taiwan (2001)

\begin{tabular}{|c|c|c|}
\hline Variables & M.L.E. (S.E.) & $\Delta$ \\
\hline Constant & $1.585(0.440)^{* *}$ & - \\
\hline Hakka & $-0.249(0.154)$ & -0.09 \\
\hline Mainlander & $-0.948(0.173)^{* *}$ & $-0.30^{* *}$ \\
\hline Aboriginal & $-0.565(0.362)$ & -0.17 \\
\hline Female & $0.013(0.099)$ & 0.00 \\
\hline Age & $-0.006(0.004)$ & -0.15 \\
\hline Income & $0.008(0.018)$ & 0.03 \\
\hline Education & $-0.078(0.024)^{* *}$ & $-0.32^{* *}$ \\
\hline Ideology & $-0.074(0.031)^{* *}$ & $-0.27^{* *}$ \\
\hline Unification & $-0.106(0.021)^{* *}$ & $-0.39^{* *}$ \\
\hline Environment & $-0.007(0.020)$ & -0.03 \\
\hline Welfare & $0.051(0.026)^{*}$ & $0.17^{*}$ \\
\hline Reform & $-0.021(0.019)$ & -0.08 \\
\hline $\begin{array}{l}\text { Political } \\
\text { Sophistication }\end{array}$ & $-0.322(0.372)$ & -0.12 \\
\hline $\begin{array}{l}\text { Sociotropic } \\
\text { Evaluation }\end{array}$ & $0.677(0.307)^{*}$ & $0.46^{*}$ \\
\hline $\begin{array}{l}\text { Pocketbook } \\
\text { Evaluation }\end{array}$ & $0.276(0.241)$ & 0.20 \\
\hline $\begin{array}{l}\text { Sophistication } \times \\
\text { Sociotropic } \\
\text { Evaluation }\end{array}$ & $-0.551(0.420)$ & -0.32 \\
\hline $\begin{array}{l}\text { Sophistication } \times \\
\text { Pocketbook } \\
\text { Evaluation }\end{array}$ & $-0.064(0.328)$ & -0.05 \\
\hline Log Likelihood & -479.00 & \\
\hline $\operatorname{LR} \chi^{2}$ & $144.30(17)^{* *}$ & \\
\hline Pseudo $\mathrm{R}^{2}$ & 0.154 & \\
\hline$\%$ Predicted Correctly & $69.61 \%$ & \\
\hline \% Reduction in Error & $27.45 \%$ & \\
\hline $\mathrm{N}$ & 836 & \\
\hline
\end{tabular}

Note: Marginal effects $(\Delta)$ indicate the change in the predicted probability of $Y$ given a discrete change in $X$ from its minimum to maximum, while holding other variables at their mean values (modal values for dichotomous variables). Marginal effects computed using Clarify (King, Tomz, and Wittenberg 2000).

${ }^{* *} \mathrm{p}<.01$, one-tailed test; ${ }^{*} \mathrm{p}<.05$, one-tailed test.

no evidence of pocketbook voting for those two standard deviations below the sophistication mean, growing to marginal significance for those one standard deviation below, and becoming strongly significant for those at and above the mean. Thus, the Taiwanese case does provide some support for our hypotheses, if not as unambiguously as the Canadian and Mexican ones. 


\section{TABLE 6 Marginal Effect of Pocketbook Evaluations on Vote Choice Given Levels of Sophistication}

\begin{tabular}{lcccc}
\hline Level of Sophistication & Canada & Mexico & Hungary & Taiwan \\
\hline -2 Standard Deviations & -0.039 & -0.027 & 0.089 & 0.102 \\
& $(0.049)$ & $(0.020)$ & $(0.070)$ & $(0.079)$ \\
-1 Standard Deviation & 0.024 & -0.016 & $0.078^{*}$ & $0.099^{*}$ \\
& $(0.031)$ & $(0.015)$ & $(0.049)$ & $(0.051)$ \\
Mean & $0.087^{* *}$ & -0.001 & $0.063^{* *}$ & $0.093^{* *}$ \\
& $(0.022)$ & $(0.011)$ & $(0.028)$ & $(0.031)$ \\
+1 Standard Deviation & $0.147^{* *}$ & 0.016 & $0.048^{*}$ & $0.086^{* *}$ \\
& $(0.030)$ & $(0.015)$ & $(0.034)$ & $(0.036)$ \\
+2 Standard Deviations & $0.163^{* *}$ & $0.032^{*}$ & 0.036 & $0.082^{* *}$ \\
& $(0.035)$ & $(0.023)$ & $(0.054)$ & $(0.047)$ \\
\hline
\end{tabular}

Note: Entries denote the conditional marginal effect of $X$ (pocketbook evaluations) on $Y$ (vote choice) at a given level of $Z$ (political sophistication), and standard errors are presented in parentheses. Computed using program associated with Brambor, Clark, and Golder (2006).

${ }^{* *} \mathrm{p}<.01$, one-tailed test; ${ }^{*} \mathrm{p}<.05$, one-tailed test.

In sum, it would appear that political sophistication is a prerequisite if citizens are to use their own economic well-being as a rubric for measuring government performance. On the surface, this conclusion seems rather similar to that reached by Duch (2001). A closer analysis, however, reveals that the theoretical foundations of the two claims are quite different. Duch argues that heterogeneity in economic voting stems from differential levels of knowledge about the economy-in other words, those citizens with some reasonable grasp of aggregate economic conditions can engage in economic voting, while those who lack such rudimentary economic data cannot. If this were the case, however, then we should expect to see significant variations, both within and potentially between countries, in sociotropic voting. We do not; in all four countries, sociotropic voting is unaffected by citizens' levels of political sophistication. Instead, it is pocketbook voting, where economic information would appear to be constant (everybody knows how they themselves are doing financially), that is subject to significant heterogeneity. Thus, it appears that differences in the cognitive process of attribution, rather than in simple economic information, are at work.

\section{Discussion}

For decades, scholars have examined empirically the extent to which citizens hold elected officials responsible for economic conditions. For a longer period of time, indeed centuries longer, political theorists have pondered the capacity of democratic publics to control government. The two questions, of course, are inherently related (the former simply being derivative of the latter). Yet, while theorists have long argued the benefits of an informed citizenry for democratic accountability, political scientists studying economic voting, with only a few exceptions, have not articulated the intellectual requisites for ascribing economic accountability. The theory and findings presented in this article seek to remedy this oversight, and, in this pursuit, we believe that we offer compelling contributions to the study of both economic voting and democratic accountability.

Our theory of heterogeneous attribution and the associated evidence clearly challenges the conventional wisdom on political sophistication and economic voting. By considering the psychological foundations of the economic vote and reconceptualizing the phenomenon fundamentally as a problem of attribution rather than information acquisition, we are able to generate hypotheses that run strongly counter to what has typically been assumed. It is the more sophisticated, not the less, as has been previously argued, who are most likely to vote their pocketbook. Moreover, the dependence of pocketbook voting on political sophistication is established here in widely varying cultural, institutional, and political contexts. Coupled with supportive work in the American case (Gomez and Wilson 2001, 2003), the results presented here make the traditional image of the pocketbook voter as a political naif simply unsustainable.

The comparative nature of our design may also shed light on some of the inconsistencies in economic voting, 
both within and between countries, uncovered by previous work. The general consistency of our results across the four very different polities that we examine argues strongly for a cognitive explanation of variations in economic voting, in addition to (if not instead of) institutional or cultural ones. If heterogeneity in economic voting is indeed a product of differential levels of political sophistication, as we demonstrate in this study, then it should come as no surprise that the scope and type of economic voting should vary significantly in different national contexts. Citizens in some polities possess, on average, much higher levels of political information than citizens of other countries; as a result, those societies' aggregate propensity for pocketbook voting should presumably be greater. While widely varying knowledge items prevent us from making such direct and absolute cross-national comparisons in the present study, this theoretical expectation provides an intriguing and essential avenue for future research.

Finally, and perhaps most importantly, our work has implications for governmental economic accountability in democratic societies. Our theory and findings suggest that some appreciable level of political knowledge and understanding is essential if citizens are to hold governments responsible for the economic conditions that they encounter in their daily lives (manifested in pocketbook voting).$^{20}$ This is a finding that holds in societies with high levels of education and in those with much lower average levels, in nascent democracies and in venerable ones. In a sense, the message of this article is one of universality. The same cognitive processes that shape economic voting in a long-established democracy like Canada are at work in Mexico, Hungary, and Taiwan as well. In all of these countries, the politically unsophisticated fail to hold governments accountable for the economic decisions that hit close to home. This empirical finding clearly supports the typically normative claim that a politically knowledgeable citizenry is a necessary (though not sufficient) condition for democratic control of government. However, the result also suggests an intriguing-some might say perverse-implication for governmental responsiveness. If our claims are true and the politically unsophisticated do not vote their pocketbook, strategic incumbents may have little incentive to be concerned with the economic

\footnotetext{
${ }^{20}$ This is not to say that crediting or blaming government is always the "correct" attribution for pocketbook circumstances. Sophisticated voters may identify causal links that low sophisticates fail to see. It is also possible, however, that some sophisticated voters have an overly politicized worldview, and thus make questionable attributions of pocketbook change to government policy. In either case, the cognitive patterns and biases that we find here would obtain.
}

well-being of the politically unsophisticated, who are also generally the poorer and more socially disadvantaged. This, in turn, has potentially troubling implications for just whom governments will be responding to with their economic policies, if they are responsive at all.

\section{Appendix Measuring Political Sophistication}

Political sophistication, as employed in this study, is rooted in the psychological notion of cognitive complexity. The two key elements of cognitive complexity are differentiation, the ability to use multiple distinct evaluative dimensions to process information and interpret events, and integration, the ability to make ordered intellectual connections between diffuse objects and ideas (Neuman 1981; Tetlock 1983). In focusing on cognitive complexity as the root of political sophistication we closely follow Sniderman, Brody, and Tetlock, who argue:

Political sophistication is a 'bundle' concept. It packs together related, if distinguishable properties including a tendency to pay close attention to politics, to have ready at hand banks of information about it, to understand multiple arguments for and against particular issue positions, and to recognize interrelationships among those arguments. $(1991,21)$

In practice, some components of this "bundle" are easier to quantify than others. Given that our present study is broad in scope and based on mass surveys rather than laboratory experiments, we necessarily focus our measurement more on attention to politics and political information than on the ability to process multiple political arguments (though we would expect these to be strongly correlated-see Delli Carpini and Keeter 1993; Neuman 1981; Sniderman, Brody, and Tetlock 1991). Thus, the key is to find, for each country examined, items that accurately tap citizen knowledge of public affairs and cognitive engagement with politics.

In the Canadian case, the 2000 CES contains a battery of political information items very similar in form and content to those that have become standard in the American National Election Studies. The eight knowledge items in the study are as follows (with percentage of respondents answering correctly):

(Q1) We're wondering how well known the federal party leaders are. Do you happen to recall the 
name of the leader of the Federal New Democratic Party? (44\% correct)

(Q2) And the leader of the Federal Conservative Party? (65\% correct)

(Q3) The leader of the Alliance Party? (69\% correct)

(Q4) The leader of the Federal Liberal Party? (84\% correct)

(Q5) Do you recall the name of the Minister of Finance of Canada? (65\% correct)

(Q6) Do you recall the approximate size of the federal budget surplus? (29\% correct)

(Q7) Do you happen to recall the name of the Prime Minister of Canada at the time of the Free Trade Agreement with the United States? (54\% correct)

(Q8) And do you happen to know the capital of the United States? (83\% correct)

We tally correct responses to these items to form a 9-point political sophistication scale, ranging from 0 to 8 . Principal components factor analysis with orthogonal varimax rotation confirms the unity of the items comprising this scale, as all variables load on a single factor (eigenvalue $=$ 3.09; Cronbach's $\alpha=0.83) .{ }^{21}$

In the Mexican case, the 1997 CIDE study includes six political-knowledge items. These focus more on constitutional rules and political process than on the identification of officeholders, but still seem to tap individuals' cognitive engagement with politics. They are as follows (with percentage of respondents answering correctly): ${ }^{22}$

(Q1) Do you remember the names of any of the candidates for federal deputy who ran in your district in this past election? (30\% correct)

(Q2) To have control of the Chamber of Deputies, a political party must have more than half of the deputies. Do you know if any party obtained more than half of the deputies in the election this past July $6^{\text {th }}$ ? ( $18 \%$ correct)

(Q3) In general, for how many years does the term of a deputy last? ( $54 \%$ correct)

(Q4) And the President of the Republic? (89\% correct)

\footnotetext{
${ }^{21}$ Factor loadings for Canada are: $\mathrm{Q} 1=.67, \mathrm{Q} 2=.78, \mathrm{Q} 3=.75$, $\mathrm{Q} 4=.60, \mathrm{Q} 5=.63, \mathrm{Q} 6=.39, \mathrm{Q} 7=.56, \mathrm{Q} 8=.49$.

${ }^{22}$ In Mexico, of course, as in Hungary and Taiwan, the original survey questions were not asked in English. What we present here are translations, done by the authors in the case of Mexico and provided by the original survey investigators in the cases of Hungary and Taiwan.
}

(Q5-6) As far as you know, what are the chambers that comprise the Mexican Congress? (48\% and $42 \%$ correct)

Again, factor analysis confirms the unity of this 7-point scale. All items load on a single factor (eigenvalue $=2.00$; Cronbach's $\alpha=0.68) .{ }^{23}$

In the Hungarian case, the 1997 University of Houston-Ezredvég Alapítvány study contains five questions that can be used to form a sophistication scale. These are somewhat less conventional political information items than exist for the other countries, since two of them measure economic, as opposed to strictly political, knowledge. The available questions are (with percentage of respondents answering correctly):

(Q1-2) Could you tell us which parties form the government? (78\% and 70\% correct)

(Q3) In your opinion, approximately how many out of 100 are unemployed in Hungary today? (30\% correct)

(Q4) In your opinion in the last year by how many percents [sic] have the prices risen? (48\% correct) (Q5) Can you tell me how many votes a voter can cast in the first round of the Parliamentary election? (24\% correct)

For questions 3 and 4, responses are coded correct if they are within $5 \%$ of the true values. Even though we are forced in this case to use economic as well as political items in order to create a scale, factor analysis confirms the items' underlying unity. All five questions load on a single factor (eigenvalue $=1.58$; Cronbach's $\alpha=0.62){ }^{24}$

Finally, in the Taiwanese case, the 2001 National Chengchi University study includes a battery of five political-knowledge items very similar to those in the ANES and CES. They are (with percentage of respondents answering correctly):

(Q1) Who is the current Vice President of Taiwan? (95\% correct)

(Q2) Who is the President of the People's Republic of China? (73\% correct)

(Q3) Who is the current President of the United States? (81\% correct)

(Q4) How many years is a legislator's term? (28\% correct)

\footnotetext{
${ }^{23}$ Factor loadings for Mexico are: $\mathrm{Q} 1=.15, \mathrm{Q} 2=.32$, $\mathrm{Q} 3=.46$, $\mathrm{Q} 4=.35, \mathrm{Q} 5=.87, \mathrm{Q} 6=.88$.

${ }^{24}$ Factor loadings for Hungary are: $\mathrm{Q} 1=.80, \mathrm{Q} 2=.82, \mathrm{Q} 3=.28$, $\mathrm{Q} 4=.29, \mathrm{Q} 5=.34$
} 
(Q5) Which body has the power to interpret the Constitution? (33\% correct)

As in the previous cases, we combine these items to form a 6-point political sophistication scale. All five items load on a single factor (eigenvalue $=2.12$; Cronbach's $\alpha=0.78) .{ }^{25}$ In a sense, these items are a more problematic gauge of political sophistication than those from the other countries because they are relatively easy-almost $75 \%$ of respondents answered more than half of the questions correctly, with the large majority clustering at three or four correct answers. Thus, we have considerably less variance in our sophistication index for Taiwan than we would ideally desire.

\section{References}

Alesina, Alberto, John Londregan, and Howard Rosenthal. 1993. "A Model of the Political Economy of the United States." American Political Science Review 87(March):12-33.

Alford, John R., and Jerome S. Leege, Jr. 1984. "Economic Conditions and Individual Vote in the Federal Republic of Germany." Journal of Politics 46(November):1168-81.

Arcelus, Francisco, and Allan H. Meltzer. 1975. "The Effects of Aggregate Economic Variables on Congressional Elections." American Political Science Review 69(December):1232-39.

Bandura, Albert. 1982. "Self-Efficacy Mechanism in Human Agency." American Psychologist 37(2):122-47.

Booth, John A., and Patricia Bayer Richard. 1998. "Civil Society, Political Capital, and Democratization in Central America." Journal of Politics 60(August):780-800.

Brambor, Thomas, William Roberts Clark, and Matt Golder. 2006. "Understanding Interaction Models: Recommendations for Improving Empirical Analyses." Political Analysis. Forthcoming.

Campbell, Angus, Philip E. Converse, Warren E. Miller, and Donald E. Stokes. 1960. The American Voter. New York: Wiley.

Clarke, Harold D., and Marianne C. Stewart. 1994. "Prospections, Retrospections, and Rationality: The 'Bankers' Model of Presidential Approval Reconsidered.” American Journal of Political Science 38(November):1104-23.

Conover, Pamela Johnston, Stanley Feldman, and Kathleen Knight. 1986. "Judging Inflation and Unemployment: The Origins of Retrospective Evaluations." Journal of Politics 48(August):565-88.

Converse, Philip E. 1964. "The Nature of Belief Systems in Mass Publics." In Ideology and Discontent, ed. David E. Apter. New York: Free Press, 206-61.

Delli Carpini, Michael X., and Scott Keeter. 1993. "Measuring Political Knowledge: Putting First Things First." American Journal of Political Science 37(November):1179-206.

${ }^{25}$ Factor loadings for Taiwan are: $\mathrm{Q} 1=.56, \mathrm{Q} 2=.72, \mathrm{Q} 3=.75$, $\mathrm{Q} 4=.63, \mathrm{Q} 5=.57$.
Delli Carpini, Michael X., and Scott Keeter. 1996. What Americans Know About Politics and Why It Matters. New Haven: Yale University Press.

Dominguez, Jorge I., and James A. McCann. 1996. Democratizing Mexico: Public Opinion and Electoral Choices. Baltimore: Johns Hopkins University Press.

Downs, Anthony. 1957. An Economic Theory of Democracy. New York: Harper.

Duch, Raymond M. 2001. "A Developmental Model of Heterogeneous Economic Voting in New Democracies." American Political Science Review 95(December):895-910.

Duch, Raymond M., Harvey D. Palmer, and Christopher J. Anderson. 2000. "Heterogeneity in Perceptions of National Economic Conditions." American Journal of Political Science 44(October):635-52.

Epstein, Leon. 1964. "A Comparative Study of Canadian Parties.” American Political Science Review 58(March):46-59.

Feldman, Stanley. 1982. "Economic Self-Interest and Political Behavior." American Journal of Political Science 26(August):446-66.

Fiorina, Morris P. 1981. Retrospective Voting in American National Elections. New Haven: Yale University Press.

Fiske, Susan T., and Shelley E. Taylor. 1984. Social Cognition. New York: Random House.

Freedom House. 2003. Freedom in the World 2003: The Annual Survey of Political Rights and Civil Liberties. Lanham, MD: Rowman and Littlefield.

Friedrich, Robert J. 1982. "In Defense of Multiplicative Terms in Multiple Regression Equations.” American Journal of Political Science 26(November):797-833.

Gomez, Brad T., and J. Matthew Wilson. 2001. "Political Sophistication and Economic Voting in the American Electorate: A Theory of Heterogeneous Attribution." American Journal of Political Science 45(October):899-914.

Gomez, Brad T., and J. Matthew Wilson. 2003. "Causal Attribution and Economic Voting in American Congressional Elections." Political Research Quarterly 56(September):271-82.

Harper, Marcus A. G. 2000. "Economic Voting in Postcommunist Eastern Europe." Comparative Political Studies 33(November):1191-227.

Heider, Fritz. 1958. The Psychology of Interpersonal Relations. New York: Wiley.

Hetherington, Marc J. 1996. “The Media’s Role in Forming Voters' National Economic Evaluations in 1992." American Journal of Political Science 40(May):372-95.

Hewstone, Miles. 1989. Causal Attribution. Oxford: Basil Blackwell.

Hibbs, Douglas A., Jr., R. Douglas Rivers, and Nicholas Vasilatos. 1982. "On the Demand for Economic Outcomes: Macroeconomic Performance and Mass Political Support in the United States, Great Britain, and Germany." Journal of Politics 44(May):426-61.

Hilton, Denis J., and Ben R. Slugoski. 1986. "Knowledgebased Causal Attribution: The Abnormal Conditions Focus Model." Psychological Review 93(January):7588.

Hsieh, John Fuh-sheng. 2003. "The Logic of (a Special Type of) Semi-Presidentialism: Loopholes, History, and Political Conflicts." Paper presented at Academia Sinica Conference 
on Semi-Presidentialism and Nascent Democracies, Taipei, Taiwan.

Inglehart, Ronald. 1977. The Silent Revolution. Princeton: Princeton University Press.

Iyengar, Shanto. 1989. "How Citizens Think About National Issues: A Matter of Responsibility." American Journal of Political Science 33(November):878-900.

Jacoby, William G. 1995. “The Structure of Ideological Thinking in the American Electorate." American Journal of Political Science 39(May):314-35.

Kinder, Donald R., and D. Roderick Kiewiet. 1979. "Economic Discontent and Political Behavior: The Role of Personal Grievances and Collective Economic Judgments in Congressional Voting." American Journal of Political Science 23(August):495-527.

Kinder, Donald R., and D. Roderick Kiewiet. 1981. "Sociotropic Politics: The American Case." British Journal of Political Science 11(April):129-61.

Kinder, Donald R., and Walter R. Mebane. 1983. "Politics and Economics in Everyday Life." In The Political Process and Economic Change, ed. Kristen Monroe. New York: Agathon, 141-180.

King, Gary, Michael Tomz, and Jason Wittenberg. 2000. "Making the Most of Statistical Analyses: Improving Interpretation and Presentation." American Journal of Political Science 44(April):347-61.

Klesner, Joseph L. 1997. “The Mexican Midterm Congressional and Gubernatorial Elections of 1997: End of the Hegemonic Party System.” Electoral Studies 16(December):567-75.

Knight, Kathleen. 1985. "Ideology in the 1980 Election: Ideological Sophistication Does Matter." Journal of Politics 47(August):828-53.

Kramer, Gerald H. 1971. "Short-term Fluctuations in U.S. Voting Behavior, 1896-1964." American Political Science Review 65(March):131-43.

Kramer, Gerald H. 1983. "The Ecological Fallacy Revisited: Aggregate Versus Individual-level Evidence on Economics and Elections and Sociotropic Voting." American Political Science Review 77(March):92-111.

Krause, George A. 1997. "Voters, Information Heterogeneity, and the Dynamics of Aggregate Economic Expectations." American Journal of Political Science 41(October):1170-200.

Lancaster, Thomas D., and Michael S. Lewis-Beck. 1986. "The Spanish Voter: Tradition, Economics, Ideology." Journal of Politics 48(August):648-74.

Lau, Richard R., and David O. Sears. 1981. "Cognitive Links Between Economic Grievances and Political Responses." Political Behavior 3(4):279-302.

LeDuc, Lawrence. 2002. "The Federal Election in Canada, November 2000.” Electoral Studies 21(December):655-59.

Lewis-Beck, Michael S. 1983. "Economics and the French Voter: A Microanalysis." Public Opinion Quarterly 47(Autumn):347-60.

Lewis-Beck, Michael S. 1988. Economics and Elections: The Major Western Democracies. Ann Arbor: University of Michigan Press.

Lewis-Beck, Michael S., and Martin Paldam. 2000. "Economic Voting: An Introduction.” Electoral Studies 19(June):11321.
Linz, Juan J., and Alfred Stepan. 1996. Problems of Democratic Transition and Consolidation: Southern Europe, South America, and Post-Communist Europe. Baltimore: Johns Hopkins University Press.

Luskin, Robert L. 1987. "Measuring Political Sophistication." American Journal of Political Science 31(November):856-99.

MacKuen, Michael B., Robert S. Erikson, and James A. Stimson. 1992. "Peasants or Bankers? The American Electorate and the U.S. Economy." American Political Science Review 86(September):597-611.

Madsen, Douglas. 1987. “Political Self-Efficacy Tested.” American Political Science Review 81(June):571-82.

Manin, Bernard, Adam Przeworski, and Susan C. Stokes. 1999. "Elections and Representation." In Democracy, Accountability, and Representation, ed. Adam Przeworski, Susan C. Stokes, and Bernard Manin. Cambridge: Cambridge University Press, pp. 29-54.

Markus, Gregory B. 1988. "The Impact of Personal and National Economic Conditions on the Presidential Vote: A Pooled Cross-Sectional Analysis." American Journal of Political Science 32(February):137-54.

Monroe, Kristen, and Lynda Erickson. 1986. "The Economy and Political Support: The Canadian Case.” Journal of Politics 48(August):616-47.

Nannestad, Peter, and Martin Paldam. 1994. "The VP-Function: A Survey of the Literature on Vote and Popularity Functions After 25 Years." Public Choice 79(3-4):213-45.

Nannestad, Peter, and Martin Paldam. 1997. “The Grievance Asymmetry Revisited: A Micro Study of Economic Voting in Denmark, 1986-92." European Journal of Political Economy 13(February):81-99.

Neuman, W. Russell. 1981. "Differentiation and Integration: Two Dimensions of Political Thinking." American Journal of Sociology 86(May):1236-68.

O’Donnell, Guillermo A., Philippe C. Schmitter, and Laurence Whitehead, eds. 1986. Transitions from Authoritarian Rule: Prospects for Democracy. Baltimore: Johns Hopkins University Press.

Peffley, Mark, and John T. Williams. 1985. "Attributing Presidential Responsibility for National Economic Problems." American Politics Quarterly 13(October):393-425.

Petty, Richard E., and John T. Cacioppo. 1996. Attitudes and Persuasion: Classic and Contemporary Approaches. Boulder: Westview Press.

Powell, G. Bingham, Jr., and Guy D. Whitten. 1993. "A CrossNational Analysis of Economic Voting: Taking Account of the Political Context." American Journal of Political Science 37(May):391-414.

Powers, Denise V., and James H. Cox. 1997. "Echoes from the Past: The Relationship between Satisfaction with Economic Reforms and Voting Behavior in Poland." American Political Science Review 91(September):617-33.

Putnam, Robert D. 1993. Making Democracy Work: Civic Traditions in Modern Italy. Princeton: Princeton University Press.

Putnam, Robert D., ed. 2002. Democracies in Flux: The Evolution of Social Capital in Contemporary Society. Oxford: Oxford University Press.

Sanders, David. 1999. "Conservative Incompetence, Labour Responsibility and the Feelgood Factor: Why the Economy 
Failed to Save the Conservatives in 1997.” Electoral Studies 18(June):251-70.

Schafferer, Christian. 2003. "The Legislative Yuan Election, Taiwan 2001." Electoral Studies 22(September):532-37.

Sniderman, Paul M. 1993. "The New Look in Public Opinion Research." In Political Science: The State of the Discipline II, ed. Ada W. Finifter. Washington: American Political Science Association, pp. 219-45.

Sniderman, Paul M., Richard A. Brody, and Philip E. Tetlock. 1991. Reasoning and Choice: Explorations in Political Psychology. Cambridge: Cambridge University Press.
Tetlock, Philip E. 1983. "Accountability and Complexity of Thought." Journal of Personality and Social Psychology 45(July):74-83.

Weatherford, M. Stephen. 1983. "Economic Voting and the 'Symbolic Politics' Argument: A Reinterpretation and Synthesis." American Political Science Review 77(March):15874.

Zanna, Mark P., Ellen C. Klosson, and John M. Darley. 1976. "How Television News Viewers Deal with Facts that Contradict their Beliefs: A Consistency and Attribution Analysis." Journal of Applied Social Psychology 6(April-June):159-76. 